Acta Agroph., 2018, 25(4), 501-509

doi: $10.31545 /$ aagr/102827

\title{
THE INFLUENCE OF FLOREDUX, MAXCEL AND BREVIS ON THE YIELD OF APPLE TREES CV. ŠAMPION
}

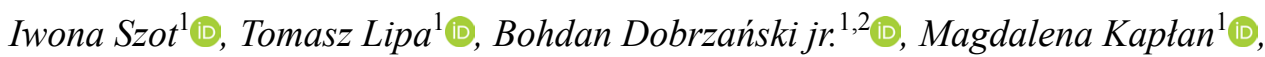 \\ Piotr Baryta ${ }^{1}$ \\ ${ }^{1}$ Department of Pomology and Nursery, Faculty of Horticulture and Landscape Architecture \\ Lublin University of Life Sciences, S. Leszczyńskiego 58, 20-068 Lublin, Poland \\ ${ }^{2}$ Bohdan Dobrzański Institute of Agrophysics, Polish Academy of Sciences \\ Doświadczalna 4, 20-290 Lublin, Poland \\ e-mail: szoti@autograf.pl
}

\begin{abstract}
Flower or fruitlet thinning is one of the cultural practices used for improving the fruit quality and regulation of yield. The effect of ATS (FloreduX), 6-BA (MaxCel) and metamitron (Brevis) on yield and some fruit characteristics of apple trees cv. Šampion/ M.9 T337 was evaluated. Chemical thinning agents were applied alone, as subsequent spraying or as a tank mixture. Due to the possibility of damage to flowers by the announced frosts, a preparation containing sea algae - Goëmar was added in some treatments. Thinning with only MaxCel resulted in an excessive reduction of the total yield expressed in the number of fruits and their mass, but using MaxCel after flower thinning with Floredux gave very good results. The total yield expressed in $\mathrm{kg} /$ tree was even bigger than in the control, but the share of fruits with diameter above $7.5 \mathrm{~mm}$ was much better. The most promising method of thinning apple trees cv. 'Szampion' was the use of MaxCel+Brevis, at fruitlets diameter of 10-12 mm. The yield expressed by the number of apples on a tree was much smaller than in the control, but total yield did not differ from the total yield of the control trees. Apples in this treatment were characterised by the highest mass and length, as well as large diameters. In the fruits of this treatment, there was no significant reduction in flesh firmness relative to the control, and they had the highest dry matter content.

Keyw ords: chemical thinning, hand thinning, cytokinin, fruit quality
\end{abstract}

\section{INTRODUCTION}

The benefits of apple growing depend to the regularity of yield and high external and internal quality of fruit. The condition of annual cropping is a sufficient amount of flowers on a tree, as well as adequate flower setting for the next year. This is possible only with a suitable amount of fruit on the tree. Fruits, through their 
seeds, have a negative effect on the formation of flower buds. The hormones contained in the seeds play a major role in thi

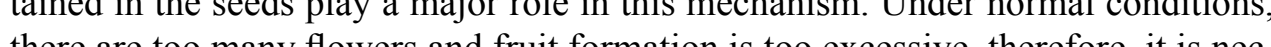
there are too men fowers and fit for necessary to perform thining. Both for herentang fruits, it is recommended to thin as early as possible (Bergh 1990). Thinning can be done during flowering (flower thinning), but most often it is made later (fruitlet thinning), due to the concerns of farmers about sufficient fruitset. Hand thinning in commercial orchards is impractical and uneconomical. Thus, nowadays, chemical fruit thinning is commonly carried out (Williams and Fallahi 1999). The availability of chemical thinning preparations is variable, as not all of them can remain on the market or be used in a given production system.

A good solution, commonly known among fruit growers, is the use of ammonium thiosulphate (ATS - preparation Floredux) at a suitable concentration. ATS works by desiccating and, therefore, damaging the stigmas and styles of apple flowers and preventing excessive fruitset. In a year when the flowering period is extended, two sprays may be required. Early thinning ha a very positive effect

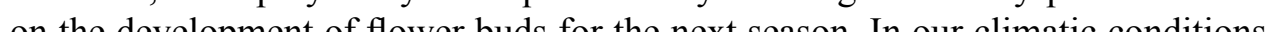
there is a high probabily of fros duing flowering period. Eaty thining with thers, is a high probability of flost duing the floweing period. Eanly thinhing with ATS, therefore, carries a risk of too much yield loss. Therefore, fruit farmers prefer to thin a little later. Curtenty in Polnd, he following preparations are registered as approved for apple fruitlet thinning: Brevis $150 \mathrm{SG}$, Exillis $020 \mathrm{SL}$, Globaryll $100 \mathrm{SL}$, and since 2017 also MaxCel. Brevis contains metamitron which is a herbicide and an inhibitor of photosystem II. Metamitron belongs to triazinone chemical group which has recently been reported as an efficient product in the thinning of apple crops (Lafer 2010, Basak 2011). It affects the photosynthetic apparatus for 7 to 10 days after application, reducing electron transport rates by up to $60 \%$ (Macartney and Obermiller 2012). Brevis $150 \mathrm{SG}$ is effective in the thinning of apple when applied at the stage from 7 to $15 \mathrm{~mm}$, and its effect may be enhanced when associated with other thinners. Exillis $020 \mathrm{SL}$, Globaryll $100 \mathrm{SL}$ and MaxCel are based on 6-BA. 6-BA is a cytokinin which not only thins apples, but it also increases fruit We size and entis a cy retun bloon for a crop in the following year (Greene 2016). BA improves fint size or weight by increasing the number of cells per fruit 20 mulation of cell division (Geene et al. 1992, Wismer et al. 1995).

The aim of this study on apple trees cv.'Šampion' was to estimate the effectiveness of chemical thinning of flowers and fruitlets with Floredux, Brevis and MaxCelalone, as a subsequent spraying or in a mixture. Due to the possibility of damage to flowers by announced frosts, a preparation containing sea algae Goëmar was added in some treatments.
MATERIAL AND METHODS

The experimental material in 2016 was apple trees of the 'Šampion'/M.9 T337 cultivar, planted in a commercial orchard in Stryjno. The trees were planted in 2010 in rows directed from north to south, with spacing of $3.3 \times 1.2 \mathrm{~m}$. The trees were trained as slender spindles. Orchard floor management consisted of grass in the interrows and 1-m wide herbicide strip in the intrarow space. Protection of trees against pests was carried out in accordance with current recommendations for fruit orchards. Fertilisation was carried out according to the YARA fertiliser program. For each combination of thinning flowers or fruitlets, 10 intensely flowering trees were selected. The apple trees were thinned according to the following scheme:

1. Control (without any thinning practices);

2. Control (without any thinning practices) $+3 \times$ Goëmar $21 \mathrm{ha}^{-1}$ in 10001 of water;

3. Hand thinning (after the June fruit drop)

4. Hand thinning (after the June fruit drop) $+3 \times$ Goëmar $21 \mathrm{ha}^{-1}$ a in 10001 of water;

5. Ammonium thiosulphate (during flowering) + BA $300 \mathrm{ppm}$ (with 10-12 mm diameter of royal buds on older wood) (Floredux $151 \mathrm{ha}^{-1}, 5001$ water ha $\left.^{-1}\right)+$ MaxCel 7.51 ha $^{-1} ; 5001$ water ha $\left.{ }^{-1}\right)$;

6. Metamitron $495 \mathrm{ppm}$ (king fruit diameter 8-10 mm) (Brevis $1.65 \mathrm{~kg}$; 5001 water ha ${ }^{-1}$;

7. Metamitron $660 \mathrm{ppm}$ (king fruit diameter 8-10 mm) (Brevis $2.2 \mathrm{~kg} ; 5001$ water ha- ${ }^{-1}$;

8. BA300 ppm (king fruit diameter 10-12 mm) (MaxCel $7.51 \mathrm{ha}^{-1} ; 5001$ water ha $\left.^{-1}\right)$;

9. Ammonium thiosulfate (during flowering) (Floredux $151 \mathrm{ha}^{-1}, 5001$ water $\mathrm{ha}^{-1}$ ) + Metamitron $495 \mathrm{ppm} / \mathrm{BA} 300 \mathrm{ppm}$ (king fruit diameter 10-12 mm) (Brevis $1.65 \mathrm{~kg}+$ MaxCel $7.51 \mathrm{ha}^{-1} ; 5001$ water ha ${ }^{-1}$ ),

10. Metamitron $495 \mathrm{ppm} / \mathrm{BA} 300 \mathrm{ppm}$ (king fruit diameter 10-12 mm) (Brevis $1.65 \mathrm{~kg}+$ MaxCel $7.51 \mathrm{ha}^{-1} ; 5001$ water ha $\left.{ }^{-1}\right)$.

At harvest time $\left(29^{\text {th }}\right.$ of September, 2016) samples of 100 fruits per treatment were randomly collected for fruit quality determinations. Quality was determined by assessing the following features:

- Total yield expressed in number of fruit tree ${ }^{-1}\left(\mathrm{No}\right.$.) and mass tree ${ }^{-1}(\mathrm{~kg})$;

- Proportion of fruit in individual size classes - on a sample of 100 fruits from every treatment that were divided in three classes: $<65 \mathrm{~mm} ; 65-75 \mathrm{~mm}$ and $>75 \mathrm{~mm}$ of fruit diameter.

- Mean fruit mass determined with a digital balance (g);

- Diameter and length of fruits determined with digital caliper (mm);

- Skin colour assessed with an arbitrary scale: 1-5 (1: no blush, 2: $1-25 \%$ of skin with blush, $3: 26-50 \%$ of skin with blush, $4: 51-75 \%$ of skin with blush, $5: 76-100 \%$ of skin with blush); 
- Flesh firmness with Magness-Taylor penetrometer (mod. FT 327) with $11 \mathrm{~mm}$ probe;

- Soluble solids content (\%) with an Abbé refractometer

- Dry matter content (\%) with the oven-drying method.

The data were statistically evaluated by analysis of variance (ANOVA) by Tukey's test at $\mathrm{P}=0.05$ ). Data were analysed using 'STATISTICA' software.

RESULTS AND DISCUSSION

Table 1. Total yield of apple trees cv. ‘Šampion’ in 2016

\begin{tabular}{|c|c|c|}
\hline Treatment & $\mathrm{N}^{\circ}$ of fruit tree $\mathrm{e}^{-1}$ & $\begin{array}{l}\text { Total yield }(\mathrm{kg} \text { tree- } \\
297 \mathrm{~d}-\mathrm{f}\end{array}$ \\
\hline 1. Control+Goëmar & $171.0 \mathrm{~d}$ & $31.32 \mathrm{ef}$ \\
\hline 3. Hand thinning & $96.0 \mathrm{ab}$ & $21.91 \mathrm{a}-\mathrm{c}$ \\
\hline 4. Hand thinning + Goëmar & $101.88 \mathrm{ab}$ & $19.49 \mathrm{ab}$ \\
\hline 5. Floredux+MaxCel & $149.50 \mathrm{~cd}$ & $34.22 \mathrm{f}$ \\
\hline $\begin{array}{l}\text { 6. Brevis } 1.65 \mathrm{~kg} \\
\text { 7 Brevis 2 2 ka }\end{array}$ & $125.25 \mathrm{bc}$ & $26.33 \mathrm{~b}-\mathrm{e}$ \\
\hline $\begin{array}{l}\text { 7. Brevis } 2.2 \mathrm{~kg} \\
\text { 8. MaxCel }\end{array}$ & $\begin{array}{l}124.13 \mathrm{bc} \\
76.13 \mathrm{a}\end{array}$ & $\begin{array}{l}27.51 \mathrm{c}-\mathrm{f} \\
17.82 \mathrm{a}\end{array}$ \\
\hline 9. Floredux + MaxCel/Brevis & $113.25 \mathrm{~b}$ & $22.24 \mathrm{a}-\mathrm{c}$ \\
\hline
\end{tabular}

${ }^{1}$ Different letters in columns indicate a significant difference in Tukey's Multiple Comparon Test

( $\mathrm{p}<0.05)$
ifferent letters in columns indicate a significant difference in Tukey's Multiple Comparison Test

Each thinning method resulted in a significant reduction in the total yield expressed as the number of apples per tree, apart from the combination where Floredux + MaxCel were used (Tab. 1). In some cases a significant decrease in the total yield expressed as $\mathrm{kg}^{-1} \mathrm{tree}^{-1}$ in comparison to the control trees was noted (treatments $3,4,8,9$ ). Only the trees where Floredux + MaxCel, Brevis $2.2 \mathrm{~kg}$, Brevis $1.65 \mathrm{~kg}$ and $\mathrm{MaxCel} / \mathrm{Brevis}$ were used (treatments $5,6,7,10$ ) had a similar mass of total yield to the control trees. Overthinning occurred after using MaxCel alone. According to McArtney and Obermiller (2014), high concentrations of metamitron can promote excessive fruit drop, requiring some care during application. In this study the total yield at the dose of Brevis of 1.65 and $2.2 \mathrm{~kg} \mathrm{ha}^{-1}$ was similar.

Each of the thinning methods improved the share of large fruits $(75-85 \mathrm{~mm}$ in diameter) and very large (above $85 \mathrm{~mm}$ in diameter), as compared to the control where there was a fruit class with a diameter of less than $6.5 \mathrm{~cm}$ (Fig. 1). In the treatment with only MaxCel, the whole crop was apples with diameters of more than $7.5 \mathrm{~cm}$. The largest share of very large fruits (more than $8.5 \mathrm{~cm}$ in diameter) was recorded in the treatment with MaxCel/Brevis. Assessing the structure and quantity of the crop, excellent results were obtained after the application of Floredux+MaxCel. The total yield expressed in $\mathrm{kg}$ tree ${ }^{-1}$ was even higher than in the control, but the share of fruit with diameter above $75 \mathrm{~mm}$ was much better.
The explanation of this may be that early thinning of apple trees during flowering reduces the competition within the tree for carbohydrates produced during photosynthesis and improves cell division in the persisting fruitlets. Most cell division occurs in the first 3-4 weeks following fruit set (Denne 1960). In addition, cytokinins promote cell division in young fruitlets (Letham 1966, Greene et al. 1992). As a result, a slight reduction in the number of fruit as compared to the control resulted in an increase in the mass of the crop. However, this was not observed in a similar treatment where after the previous flower thinning the mixture of BA and metamitron was used (Floredux+Maxcel/Brevis). This could be explained by a different mechanism of fruitlets drop. 6-BA application results in reduced polar auxin transport across the fruit pedicel and enhances the sensitivity of the abscission zone to ethylene, eventually leading to activation of the abscission zone (Botton et al. 2011). This causes the drop of the weakest fruits. Metamitron is an PSII inhibitor and in this way reduces fruit set in apples. Byers et al. (1984) stated that photosynthetic inhibitors might also enhance the activity of other thinning agents applied to apples. Perhaps this caused a greater thingin Floredux+MaxCel, as a result, not only the smallest fruits have fallen.

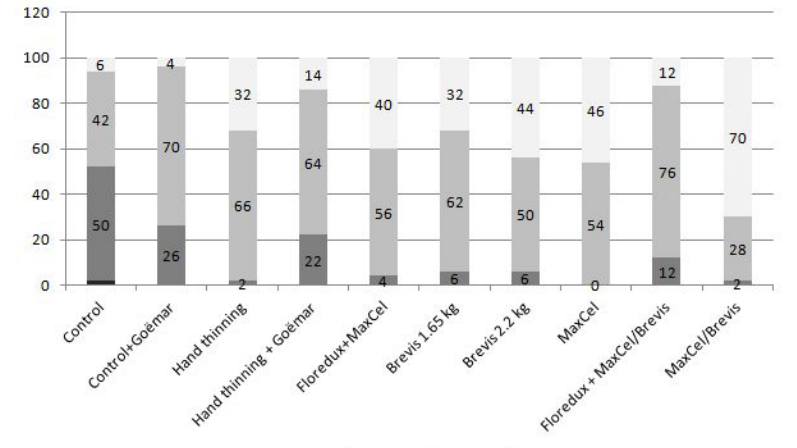

nercentage of fruit number

Each of the thinning methods resulted in a significant increase in the mean fruit mass s compared to the control trees (Tab. 2). Apples with the highest weight were recorded in the MaxCel/Brevis treatment. In the present experiment, a greater weight of fruit was btained, with crop load of 100 fruits per tree, as compared to the results of Kapłan and Baryła (2006). In the treatment Hand thinning + Goëmar the crop load was close to 100 pieces per tree and mean fruit mass was $191 \mathrm{~g}$, while in the work of Kapłan and Baryla (2006), 171-175 $\mathrm{g}$ were obtained. In most of the thinning methods an increase in fruit diameter was observed, compared to the control. Only apples from the trees where Brevis was applied at a dose of $1.65 \mathrm{~kg} \mathrm{ha}^{-1}$ had a similar diameter as the control apples. The largest diameter was observed in fruits from trees where only MaxCel was used. Each 
of the thinning methods resulted in an increase in the length of apples in relation to the control. Apples from trees where the fruitlets were thinned with $\mathrm{MaxCel} / \mathrm{Brevis}$ were characterised by the highest values of the mentioned feature. Colour and size of apple are very important criteria for consumers (Dobrzański and Rybczyński 2002). There was no significant effect of thinning on the skin colour of apple cv. 'Szampion'. Only fruits from trees where hand thinning was applied showed skin blush more intensive than the control fruits. This is consistent with findings of Maas and Meland (2016) who evaluated thinning response of 'Summer red' apple and noted that blush colour was significantly higher for apples of hand-thinned trees compared to all other treatments. Thinning achieved by the Brevis treatment did not improve the intensity of blush.

Table 2. Some external fruit quality indicators: Mean fruit mass, diameter of fruit, length of fruit, skin colour and skin russeting

\begin{tabular}{|c|c|c|c|c|}
\hline Treatment & $\begin{array}{l}\text { Mean fruit mass } \\
(\mathrm{g})\end{array}$ & $\begin{array}{l}\text { Diameter of fruit } \\
(\mathrm{mm})\end{array}$ & $\begin{array}{l}\text { Length of fruit } \\
(\mathrm{mm})\end{array}$ & $\begin{array}{l}\text { Skin colout } \\
\text { (scale 1-5) }\end{array}$ \\
\hline 1. Control & $162.78 \mathrm{a}^{1}$ & $71.60 \mathrm{a}$ & $63.00 \mathrm{a}$ & $3.72 \mathrm{a}$ \\
\hline $\begin{array}{l}\text { 2. Control+Goeme } \\
\text { 3. Hand thinning }\end{array}$ & $\begin{array}{l}183.16 \mathrm{ab} \\
228.28 \mathrm{~d}-\mathrm{f}\end{array}$ & $\begin{array}{l}75.70 \mathrm{~b} \\
8029 \mathrm{~cd}\end{array}$ & $\begin{array}{l}67.10 \mathrm{~b} \\
7091 \mathrm{~cd}\end{array}$ & $\begin{array}{l}3.92 \mathrm{ab} \\
4.44 \mathrm{~b}\end{array}$ \\
\hline 4. Hand thinning + Goëmar & $191.34 \mathrm{bc}$ & $78.20 \mathrm{bc}$ & $69.07 \mathrm{~b}-\mathrm{d}$ & $4.08 \mathrm{ab}$ \\
\hline 5. Floredux+MaxCel & $228.90 \mathrm{~d}-\mathrm{f}$ & $84.32 \mathrm{e}$ & $72.80 \mathrm{de}$ & $3.88 \mathrm{a}$ \\
\hline $\begin{array}{l}\text { 6. Brevis } 1.65 \mathrm{~kg} \\
7 \text { Brevis 2 } 2 \mathrm{~kg}\end{array}$ & $\begin{array}{l}210.21 \mathrm{~cd} \\
22167 \mathrm{de}\end{array}$ & $\begin{array}{l}76.96 \text { ab } \\
8169 \text { de }\end{array}$ & $\begin{array}{l}69.61 \mathrm{~b}-\mathrm{d} \\
70.89 \mathrm{~cd}\end{array}$ & $3.56 \mathrm{a}$ \\
\hline $\begin{array}{l}\text { 7. Brevis } 2.2 \mathrm{~kg} \\
\text { 8. MaxCel }\end{array}$ & $\begin{array}{l}221.67 \mathrm{de} \\
234.12 \mathrm{ef}\end{array}$ & $\begin{array}{l}81.69 \mathrm{de} \\
81.24 \mathrm{~d}\end{array}$ & $\begin{array}{l}70.89 \mathrm{~cd} \\
70.45 \mathrm{~b}-\mathrm{d}\end{array}$ & $\begin{array}{l}3.84 \mathrm{a} \\
3.84 \mathrm{a}\end{array}$ \\
\hline 9. Floredux + MaxCel/Brevis & $196.41 \mathrm{bc}$ & $76.04 \mathrm{~b}$ & $68.22 \mathrm{bc}$ & $3.96 \mathrm{ab}$ \\
\hline 10. $\mathrm{MaxCel} / \mathrm{Brevis}$ & $245.81 \mathrm{f}$ & $81.84 \mathrm{de}$ & $76.22 \mathrm{e}$ & $4.04 \mathrm{ab}$ \\
\hline
\end{tabular}

${ }^{1}$ Different letters in columns indicate a significant difference in Tukey's Multiple Comparison Test $(\mathrm{p}<0.05)$

Apples from trees where thinning was done by hand, Hand thinning + Goemar and Brevis $2.2 \mathrm{~kg}$, were characterised by much lower flesh firmness in relation to control apples (Tab. 3).

Table 3. Some internal fruit quality indicators: flesh fruit firmness, soluble solids content and dry matter content

\begin{tabular}{|c|c|c|c|}
\hline Treatment & $\begin{array}{l}\text { Flesh firmness } \\
\mathrm{kG} \mathrm{cm}^{-2}\end{array}$ & Soluble solids content & Dry matter content \\
\hline 1. Control & $6.87 \mathrm{de}^{1}$ & $11.95 \mathrm{ab}$ & $14.50 \mathrm{ab}$ \\
\hline Control+Goëmar & $6.76 \mathrm{~cd}$ & $11.8 \mathrm{a}$ & $13.90 \mathrm{a}$ \\
\hline Hand thinning & $6.44 \mathrm{ab}$ & $12.15 \mathrm{ab}$ & $14.95 \mathrm{ab}$ \\
\hline 4. Hand thinning + Goëmar & $6.42 \mathrm{a}$ & $12.75 \mathrm{ab}$ & $14.37 \mathrm{ab}$ \\
\hline 5. Floredux+MaxCel & $6.63 \mathrm{a}-\mathrm{d}$ & $12.00 \mathrm{ab}$ & $14.69 \mathrm{ab}$ \\
\hline 6. Brevis $1.65 \mathrm{~kg}$ & $7.09 \mathrm{e}$ & $11.90 \mathrm{ab}$ & $14.18 \mathrm{ab}$ \\
\hline $\begin{array}{l}\text { 7. Brevis } 2.2 \mathrm{~kg} \\
8 \mathrm{MaCel}\end{array}$ & $6.52 \mathrm{a}-\mathrm{c}$ & $12.20 \mathrm{ab}$ & $14.32 \mathrm{ab}$ \\
\hline 9. Floredux + $\mathrm{MaxCel} /$ Brevis & $\begin{array}{l}0.08 \mathrm{~d}-\mathrm{a} \\
6.73 \mathrm{~b}-\mathrm{d}\end{array}$ & $\begin{array}{l}12.53 \mathrm{o} \\
12.50 \mathrm{ab}\end{array}$ & $\begin{array}{l}15.03 \mathrm{D} \\
14.65 \mathrm{ab}\end{array}$ \\
\hline 10. MaxCel/Brevis & $6.74 \mathrm{~b}-\mathrm{d}$ & $12.45 \mathrm{ab}$ & $15.81 \mathrm{~b}$ \\
\hline
\end{tabular}

${ }^{1}$ Different letters in columns indicate a significant difference in Tukey's Multiple Comparison Tes $(\mathbf{p}<0.05)$
No significant effect of thinning methods on soluble solids content was found. The values of the mentioned feature were in the range from 11.8 to $12.95 \%$. There was no significant effect of thinning on dry matter content in the fruit. The smallest values of the mentioned feature were noted for Control+Goëmar treatment, and the largest after the application of MaxCel/Brevis and MaxCel alone. Greene (2014) observed that the application of metamitron in combination with BA determined slight changes in variables related to flesh firmness and soluble solids.

\section{CONCLUSIONS}

1. Thinning of apple trees cv. 'Šampion' with only MaxCel resulted in an excessive reduction of the total yield expressed in the number of fruit and its mass, but using MaxCel after flower thinning with Floredux gave very good results. The total yield expressed by $\mathrm{kg} /$ tree was even bigger than in the control, but the share of fruit with diameter above $7.5 \mathrm{~mm}$ was much better.

2. The most promising method of thinning apple trees cv. 'Šampion' was the use of MaxCel+Brevis, at fruitlet diameter of 10-12 mm. The yield expressed by the number of apples on a tree was much smaller than in the control, but the mass of the total yield did not differ from the total yield of the control trees. Apples in this treatment were characterised by the highest mass and length, as well as large diameter. In the fruits of this combination, there was no significant reduction in diameter. In the fruits of this combination, there was no significant reduction in
flesh firmness relative to the control and they had the highest dry matter content.

\section{REFERENCES}

Basak A., 2011. Efficiency of fruittet thinning in apple 'Gala Must' by use of metamitron and artificial shading. J. F. Ornam. Plant Res., 19, 51-62.

Bergh O., 1990. Effect of timing of hand thinning on apple fruit size. S. Afr. J. Plant Soil, 7(1), 1-10,

on A., Eccher G., Forcato C., Ferrarini A., Begheldo M., Zermiani M., Moscatello S., Battistelli A., Velasco R., Ruperti B., Ramina A., 2011. Signaling pathways mediating the induction of doi:10.1104/pp. 110.165779

Byers R.E., Lyons C.G., Del Valle T.B., Barden J.A., Young R.W. 1984. Peach fruit abscission by shading and photosynthetic inhibition. HortSci., 19, 649-651.

Denne M.P., 1960. The growth of apple fruitlets and the effect of early thinning on fruit development. Ann. Bot., 24(95), 397-406, doi:10.1093/oxfordjournals.aob.a083713

Dobrzański jr. B., Rybczyniski R., 2002. Color as a quality parameter of fruits and vegetables. In: Physical Methods in Agriculture (Eds J. Blahovec, M. Kutilek). Kluwer Academic Publishers, USA, $375-398$.

1451,

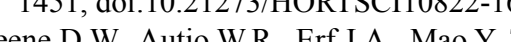

a 
Greene D.W., 2014. Use of metamitron alone and in combination with 6-benzyladenine for thinning apples. Acta Hort., 1042, 167-172, doi:10.17660/ActaHortic.2014.1042.20

Kapłan M., Baryła P., 2006. The effect of fruitlets hand thinning on the fruit quality of apple trees cultivar 'Šampion'. Annal, Univ. Marie Curie-Skłodowska Lublin - Polonia Sectio EEE, 16, 19-27.

Lafer G., 2010. Effects of chemical thinning with metamitron on fruit set, yield and fruit quality of 'Elstar'. Acta Hort., The Hague, 884, 531-536.

etham D.S., 1966. Regulators of cell division in plant tissues - II. A cytokinins in plant extracts Isolation and interaction with other growth regulators. Phytochem., 5(3), 269-286, doi:10.1016/ as F.M. Meland M., 2016.

onse of 'Summerred' apple to Brevis in a northern cliAaHortic.2016.1138.7 for delayed thinning of apple fruit. HortSci., 47(11), 1612-1616.

McArtney S.J., Obermiller J.D., 2014. Use of shading and the psII inhibitor metamitron to investiHort., 1042, 27-31, doi:10.17660/ActaHortic.2014.1042.2

Williams K.M., Fallahi E., 1999. The effects of exogenous bioregulators and environment on regular cropping of apple. Hort-

and cell size dur-

WPEYW PREPARATÓW FLOREDUX, MAXCEL I BREVIS NA PLON JABE ONI ODMIANY ŠAMPION

Iwona Szot ${ }^{1}$,Tomasz Lipa ${ }^{1}$, Bohdan Dobrzański jr. ${ }^{1,2}$, Magdalena Kaptan ${ }^{1}$ Piotr Baryla ${ }^{1}$

${ }^{1}$ Katedra Sadownictwa i Szkółkarstwa, Wydział Ogrodnictwa i Architektury Krajobrazu Uniwersytet Przyrodniczy w Lublinie, ul. S. Leszczyńskiego 58, 20-068, Lublin 2Instytut Agrofizyki im. Bohdana Dobrzańskiego Polskiej Akademii Nauk w Lublinie ul. Doświadczalna 4, 20-290 Lublin

$$
\text { e-mail: szoti@autograf.pl }
$$

Streszczenie. Przerzedzanie kwiatow lub zawiązków jest jednym z podstawowych zabiegow wykorzystywanych dia poprawy jakossci owoców i wielkości plonu. Badano wpływ ATS (FloreduX), 6-BA (MaxCel) i metamitronu (Brevis) na plon i wybrane cechy jakosciowe owocón jabloni odmiany Sampion/M.9 1337. Przerzedzanie chemiczne wykonano aplikując preparaty w kolejnych zabiegach lub $\mathrm{w}$ mieszaninie. Ze względu na niebezpieczenistwo uszkodzen kwiatôn przez zapowiadane przyPrzerzedzanie z użyciem tylko preparatu MaxCel spowodowało nadmierna redukcję plonu wyrażonego liczbą sztuk na drzewo oraz jego masą. Jednakże użycie preparatu MaxCel po wczésniejszej aplikacji $\mathrm{w}$ czasie kwitnienia preparatu Floredux okazało sie korzystne. Plon całkowity wyrażony $\mathrm{w} \mathrm{kg} \cdot \mathrm{drzewo}^{-1}$ był nawet więksszy niż w kontroli, ale udział owoców o srednicy powyżej $7,5 \mathrm{~cm}$ był znaczniejszy. Najkorzystniejzzą metodą przerzedzania jabłoni odmiany, Šampion' było zastosowanie MaxCel+Brevis,

przy średnicy 10-12 mm. Plon wyrażony liczbą owoców na drzewo był dużo niższy niż w kontroli, ale plon całkowity $\left(\mathrm{kg} \cdot\right.$ drzew $\left.^{-1}\right)$ różnił się od kontrolnego. Jabłka w tej kombinacji charakteryzowały sie najwyższa masą i długościa, jak również średnica. Ponadto jẹdrność owoców w tej kombinacji nie obniżyła się istotnie w stosunku do kontroli, a zawartość suchej masy była największa.

Słow w kluczo w e: przerzedzanie chemiczne, przerzedzanie ręczne, cytokininy, jakosć owoców 